高分子論文集 (Kobunshi Ronbunshu), Vol. 54, No. 3, pp. 138-143 (Mar., 1997)

\title{
ホルムアルデヒド架橋ゼラチン膜の特性に及ぼす ポリエチレングリコール添加効果*
}

\author{
前田拓也*1 ・元吉治雄*1
}

（受付 1996 年 9 月 9 日・審查終了 1996 年 12 月 2 日）

\begin{abstract}
要 旨 分子量の異なるポリエチレングリコール(PEG) を添加したぜラチンゲルを乾嬠した後，ホルムアルデ ヒド (FA) 蒸気と反応させて架橋した膜の物理的・化学的特性および生分解性を研究した. PEGの添加により采 軟性と䩓性が付与された。正常な膜を得るための PEG 添加量の上限や膜の外钼が PEG の分子量により変化した. 架橋時間が長くなると, FA 蒸気が膜表面から内部に浸透して架橋結合を形成し, 水への溶解性を低下させた. PEG が FA 蒸気の浸透媒体として膜内部の架橋反応を促進する作用はその分子量によって異なるため, 膜の溶解 挙動に差異が観察された. PEGの分子量が大きいほど膜の耐熱性が高く，また湿度を変化させたときの吸湿度の差 が小さかった. 引張強さは, PEGの添加により低下し, 添加量が多くなると低下の傾向は顕著になった. 延伸率之 引裂強さは, 高湿条件において, 分子量と添加量および架橋時間により差異が認められた.
\end{abstract}

1 緒言

近年, プラスチック廃棄物の処理が深刻な社会問題と なっており", リサイクルシステム ${ }^{2)}$ や燃焼装置の開発兄 などとともに, 自然環境下で微生物により分解される生 分解性プラスチックの研究も盛んに行われ, 微生物生産 系), 5), 合成高分子系(6), 7), 天然高分子系などの開発例 が報告されている. 天然高分子系としては，デンプ ン8), 9), キトサン10), グルテン (1) が検討されている.

ゼラチン (GE) は皮革副産物などから得られる天然高 分子で，価格および供給量に問題がないと考えられるこ とから ${ }^{22}$, 著者らは，GEを素材とした生分解性プラス チックの開発を行っている.これまでに, GE 単独(13) お よびグリセリン (GL) 添加 ${ }^{14)}$ の乾燥膜をホルムアルデ ヒド (FA) 蒸気と反応させて架橋した膜の特性について 検討した. その結果, FA 蒸気との反応時間を変えて, 架橋度を調整することにより生分解性を制御できること が示唆された．また，GLの添加により，膜に弾性と柔 軟性が付与されるが, 物理強度と耐熱性が低下し, 吸湿 性が大となることを認めた。

本研究では，GEに可塑㘊として平均分子量の異なる ポリエチレングリコール (PEG) を添加し, FA 蒸気で 架橋した乾燥膜の特性を調へ，GL 添加膜との差異を検 討した。

\footnotetext{
* 本報を「ゼラチンを基材とした生分解性プラスチックの開 発 第 3 報」とする.

*1 和歌山県工業技術センター（⑥49-62 和歌山市小倉 60）
}

\section{2 実験}

\section{1 膜の調製}

GE はニッピゼラチン工業(株)製（最大分子量ピー ク 100000 , 粘度 $49 \mathrm{mps}, \mathrm{pH} 6.0$, ゼリ一強度 $209 \mathrm{~g}$ ) を, PEG は平均分子量 380 420 (PEG4), 950〜1050 (PEG10), および 7400 9000 (PEG60) の片山化学 (株)製試薬一級をそのまま用いた. GE20 g に水 $120 \mathrm{ml}$ と PEG 所定量 (GE に対する wt\%) を加えて, $20^{\circ} \mathrm{C} て ゙ 1$ 時間膨潤させた後, $60^{\circ} \mathrm{C} に 30$ 分間保って溶解した. 溶 液をガラス板にキャストし，10ㄷ 3 で 時間放置してゲ ル化してから, 室温で 18 時間真空乾燥 $(15 \mathrm{~Pa})$ を行っ た. 得られた GE 乾燥膜を, $10^{\circ} \mathrm{C}$ の FA 㿣和蒸気中に 所定時間曝露して架橋した膜を試料とした．膜はいずれ も厚さが約 $0.15 \mathrm{~mm}$ であった. GE 膜の吸湿の影幚は, $23^{\circ} \mathrm{C} /$ 相対湿度 $50 \%$ (低湿) および $30^{\circ} \mathrm{C} /$ 相対湿度 $80 \%$ (高湿) の条件下に 72 時間以上保存調整して, 最大吸湿 度に達した試料を用いて検討した。

\section{2 生分解性試験}

生分解性の評価には JIS よ゙の定まった方法がなく， また GE および PEG ${ }^{15)}$ は生分解性であり, 溶解物が環 境に悪影響を与えないことから，膜の水に対する溶解性 を生分解性の目安とした，振とうフラスコに隇菌蒸留水 $150 \mathrm{ml}$ と低湿条件下で 72 時間以上調整した試料 $50 \mathrm{mg}$ を入れて $120 \mathrm{rpm} / 30^{\circ} \mathrm{C}$ で所定時間振とうし，溶液中の 有機炭素量を（株）島津製作所製 TOC500を用いて測定 し, 試料の全有機炭素量を基に振とう後の残存率を算出 した. なお, 本試験は添加量 20\%の膜について行った. 
HA 架橋ぜラチン膜の特性に及ぼす PEG 添加効果

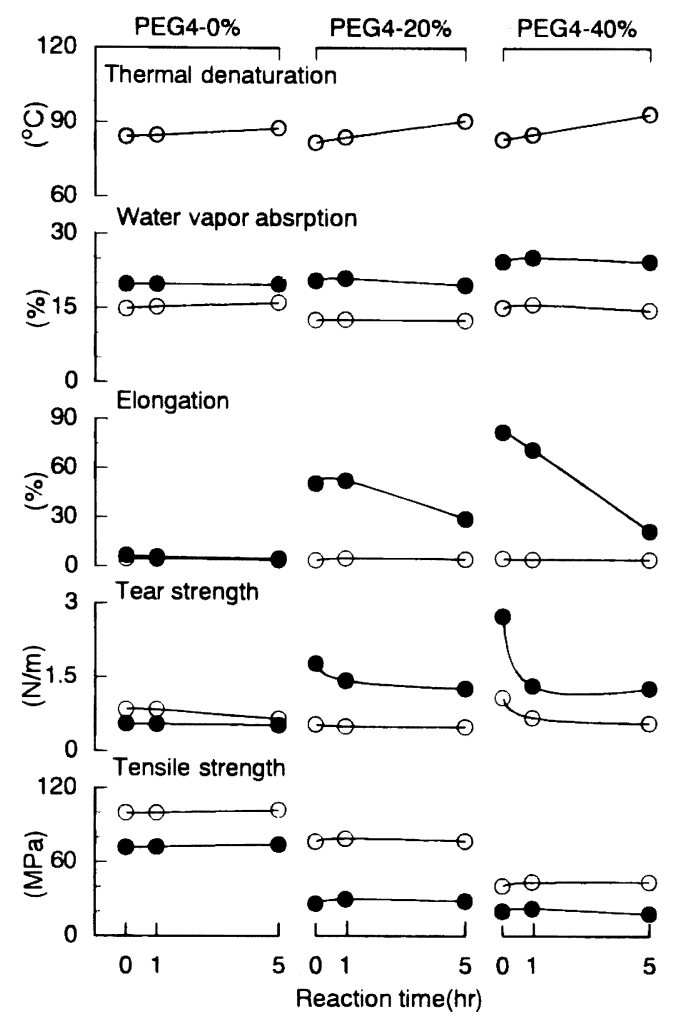

Fig. 1. Influence of PEG400 content and reaction time on properties of gelatin films. $O, 23^{\circ} \mathrm{C}, \mathbf{R H}$ $50 \%$; $, 30^{\circ} \mathrm{C}, \mathrm{RH} 80 \%$.

\section{3 物理的 - 化学的試検}

吸湿度は, $100 \times$ (吸湿膜重量一乾燥膜重量)/吸湿膜重 量により算出した，耐熱性は，低湿条件に調整した試料 $2 \mathrm{mg}$ を密封容器に封入し，セイコー電子(株)製 DSC 120 を用いて昇温速度 $5^{\circ} \mathrm{C} / \mathrm{min} に よ り$ 熱変性温度を測定 して評価した. 引張強さ, 引裂強さ, および延伸率は, 各条件で 72 時間以上保存調整した試験片を恒温恒湿器 から取り出し直ちにインストロン社製材料試験装置を用 いて室温で測定した。

\section{3 栖果と考察}

\subsection{PEG400}

得られた膜は透明で淡黄色を呈した．添加量 $40 \%$ で は高湿で膜表面に濡れが認められ，40\%以上添加する と低湿です PEG4 が出た．添加量および架橋時間 と物理的・化学的特性との関係を Fig. 1 に示す. 添加 量の影響は GLに類似していた ${ }^{14)}$. 引張強さは, 架橋時 間による差は小さく，FAによる GE の架橋結合形成 ${ }^{16)}$ の効果は少ないといえる. 添加量および湿度の增加で引 張強さが低下した．PEG4が GE の網目構造の形成を妨

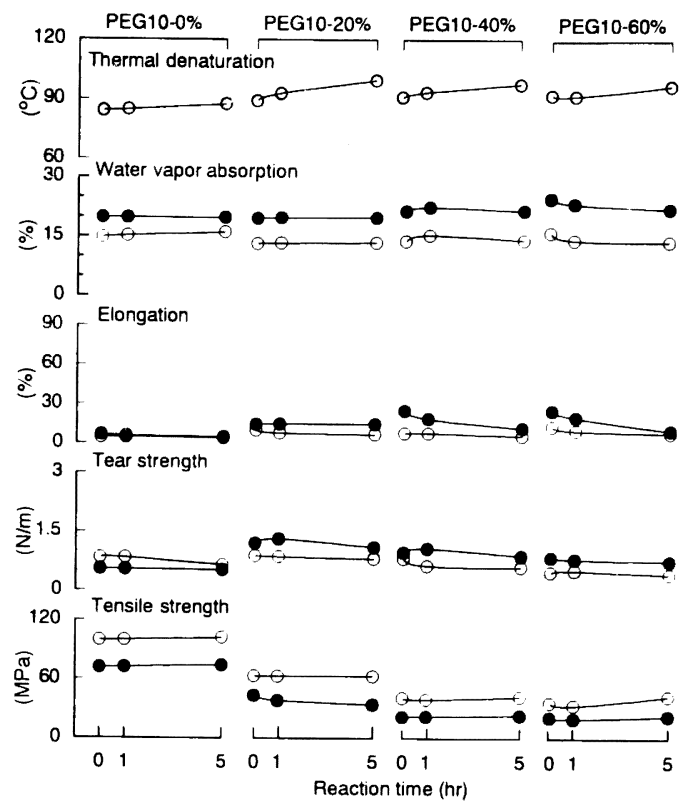

Fig. 2. Influence of PEG 1000 content and reaction time on properties of gelatin films. $O, 23^{\circ} \mathrm{C}, \mathbf{R H}$ $50 \% ; 0,30^{\circ} \mathrm{C}, \mathrm{RH} 80 \%$.

げそして弛めるため，また吸湿により水分子が網目構造 を弛楥することに起因する，延伸率は，低湿では添加量 および架橋時間による差は小さいが, 高湿では添加量が 增すと大，そして架橋時間が長くなると低下した，低湿 では網目構造が強固なため架橋度の影響は小さく, 吸湿 してこれが弛緩すると架橋による GE 分子の自由度の低 下の影響が相対的に大となるためと考える.引裂強さ は, 高湿で低湿より高い值を示し, 添加量が増すと大, そして架橋度が增すと小となった．添加量が增すと応力 緩和力が增し, 内部の架橋度が増すと GE 分子の自由度 が低下して脆くなるためである。吸湿度は, 架橋時間に よる差は小さいが, 添加量が增すと PEG4 の吸湿のた め低湿と高湿の差が大となった，耐熱性は，添加量によ る差は小さいが, 架橋時間が長くなると架橋度が増して 大となった。

\subsection{PEG1000}

得られた膜は，透明で淡黄色を呈したが，60\% 添加 した膜は高湿で表面に PEG10が白いワックス状に析出 した. $60 \%$ 以上添加すると GE がゲル化せず，正常な 膜を調製できなかった. Fig. 2 に添加量および架橋時間 と物理的・化学的特性との関係を示す. 引張強さは, PEG4 と類似の傾向を示した. すなわち, 架橋結合形成 の勃果は小さいが, PEG4 と同様の理由で添加量および 湿度の增加で低下した，延伸率と引裂強さは，高湿が低 湿よりも高い値を示したが, 添加量および架橋度の影響 
がPEG4より少なかった。これは, 網目構造への作用, 応力緩和力あるいは吸湿性などが相互に影響するためで はないか. 吸湿度は, PEG10の吸湿のために添加量が 增すと大となる．耐熱性は, PEG10の添加および FA 蒸気への曝露によって上昇した. PEG10が GE 分子を

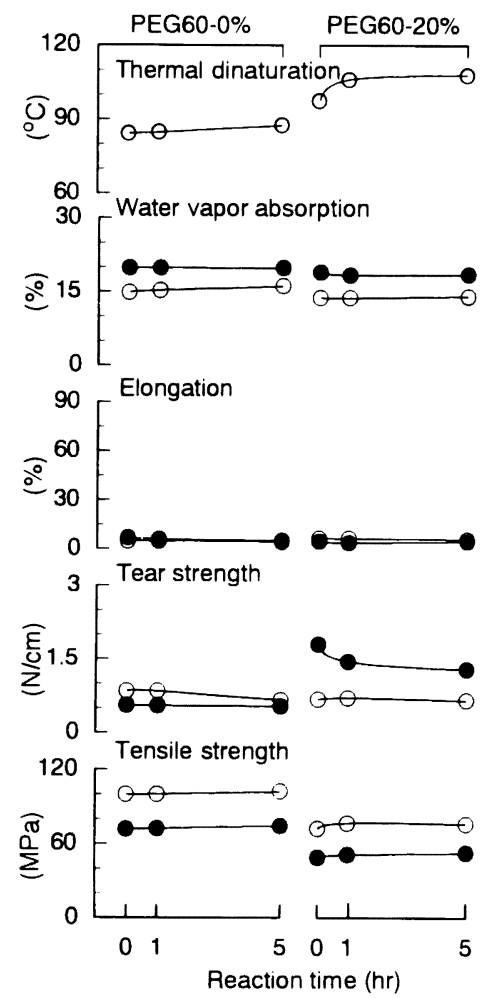

Fig. 3. Influence of PEG6000 content and reaction time on properties of gelatin films. $O, 23^{\circ} \mathrm{C}, \mathrm{RH}$ $50 \%$; $, 30^{\circ} \mathrm{C}, \mathrm{RH} 80 \%$.
熱振動から保誮すること，FA 蒸気の膜内への浸透を妨 げないことがわかった。

\subsection{PEG6000}

不透明で乳白色の膜であった． $20 \%$ 以上添加すると ゲル化せず，正常な膜が得られなかった．Fig. 3 に添加 量および架橋時間と物理的・化学的特性との関係を示 す，延伸率は，添加量，架橋時間，および吸湿の影響が 明確でない，吸湿度む，添加量および架橋時間による差 が小さかった，引張強さは，他の PEG と同様に架橋 度の効果は少ないが, 添加および吸湿により網目構造 が影響を受けて低下した，引裂強さは，応力緩和力が 変化するため, 高湿で高く, 架橋度が増すと低下した。 PEG10 と同様の作用により，添加と架橋により耐熱性 が向上した。

\section{4 可塑剤による差異}

可塑剂の種類による効果を，GE 単独および PEG ま たは GL を $20 \%$ 添加した膜で此較した。

3.4.1 生分解性 生分解性の目安として, 减菌蒸留 水への溶出物を全有機炭素量として評価し，その経時変 化を Fig. 4 に示す. 未架橋の膜はすべて数時間で完全 に溶解し，架橋時間が長くなると残存率が高くなった。 同じ架橋時間では可塑剤により異なる溶解挙動を示し た. 架橋 1 時間の GE 単独膜と PEG60 は, 溶解途中で 膜が 2 層に分離し, 他の膜は層分離が観察されなかっ た.これは，FA が膜の表面から内部に浸透して架橋結 合を形成する際に, PEG60 は浸透媒体としての作用が 弱いため, 1 時間では内部に未架橋部分が存在し，この 部分が外側より先に溶解して層分離するためである. 5 時間後にはFA が内部まで浸透するので, GE 単独膜と PEG60 6首分離を生じなかったが，架橋度が低いため 溶解が速やかだった。

3.4.2 化学的特性 Fig. 5 に吸湿度と熱変性温度を示 す. 可塑剤の種類により吸湿度が変化し，GL が最大,
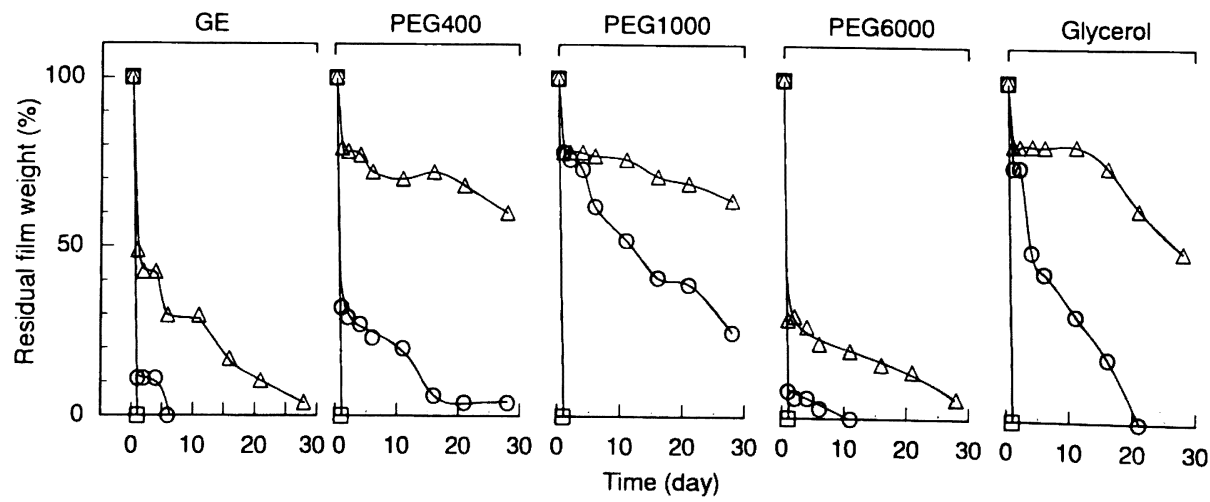

Fig. 4. Effect of molecular weight of PEG (20\% based on GE weight) and reaction time on residual film weight. Reaction time: $\square, 0 \mathrm{~h} ; \bigcirc, 1 \mathrm{~h} ; \triangle, 5 \mathrm{~h}$. 
HA 架橋ゼラチン膜の特性に及ぼす PEG 添加効果

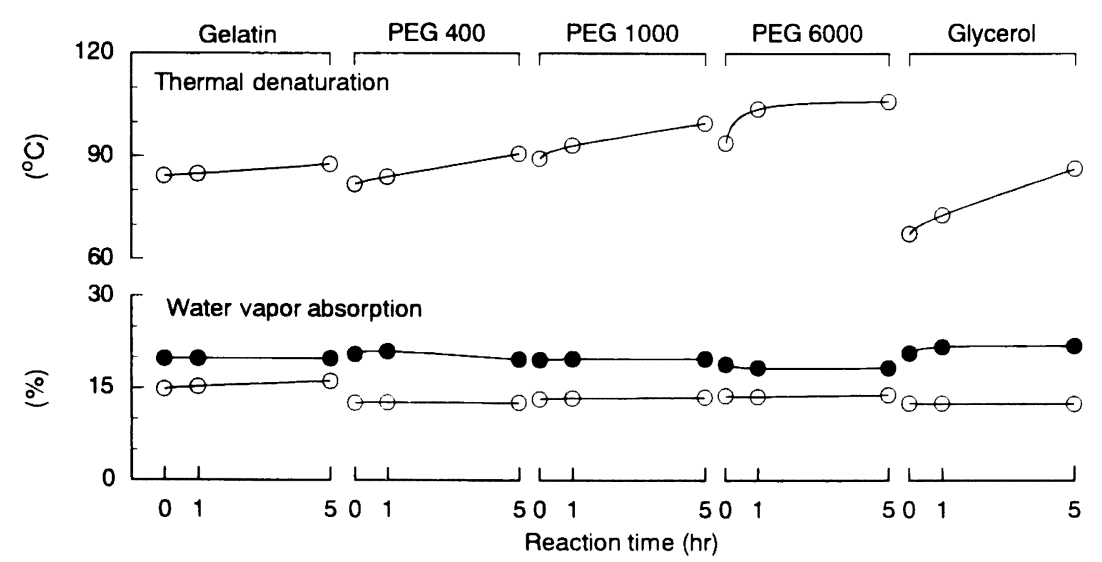

Fig. 5. Influence of molecular weight of PEG (20\% based on GE weight) and reaction time on properties of gelatin films. $\mathrm{O}, 23^{\circ} \mathrm{C}, \mathrm{RH} 50 \%$; $, 30^{\circ} \mathrm{C}, \mathrm{RH} 80 \%$.

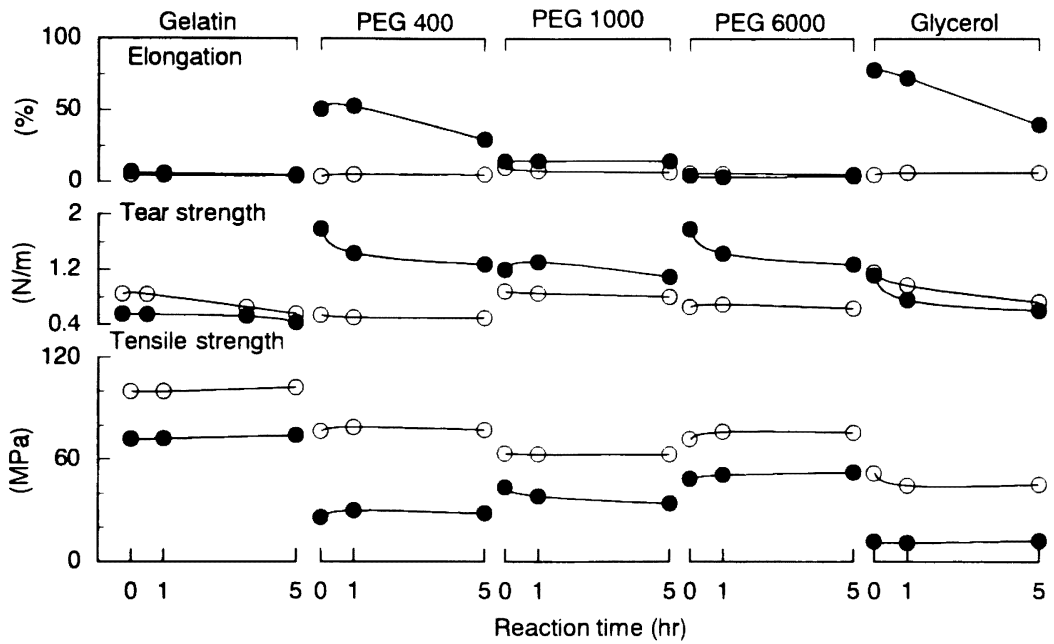

Fig. 6. Influence of molecular weight of PEG (20\% based on GE weight) and reaction time on properties of gelatin films. $\mathrm{O}, 23^{\circ} \mathrm{C}, \mathrm{RH} 50 \%$;, $30^{\circ} \mathrm{C}$, RH80\%.

PEG60が最小であった. いずれも架橋時間による差異 はわずかであり, 膜の吸湿性は GE の架橋結合形成より 6，可塑剤の吸湿性の影響を受けることがわかった．可 塑剂を添加しても架橋反応は進行し，架橋時間が長くな ると熱変性温度が高くなるが, FA の浸透促進作用およ び熱振動の伝達作用に差異があるため, GL は GE 単独 膜よりも耐熱性が低く, PEG4 は同程度, PEG10は高 く, PEG60 が最大であった.

3.4.3 物理的特性 Fig. 6 に物理的特性を示す. 添加 による引張強さの低下は GL が最大で, 高湿では PEG4 の低下が PEG10, PEG60よりも顕著であった.これは, GL が低湿であ網目構造を弛めるため, そして PEG4 が PEG10 と PEG60よりあ吸湿性がやや大であることに起
因すると考える，引裂強さは，可塑剂および吸湿による 応力緩和力と架橋による GE 分子の自由度低下が相互に 影響した，延伸率は，高湿で PEG4 と GL が高い値を 示し, 同じ架橋時間では GL が大であったが, 架橋時間 による低下も大きかった，これは，可塑剤による網目構 造および GE 分子の自由度低下への影製が異なるためで ある.

Fig. 7 は架橋 1 時間の膜の Stress-Strain 曲線である. GE 単独と PEG60 は, 低湿・高湿とも張力の増加に対 する伸びの增加が微少な脆性変形機構による非弾性変形 を示し，硬くて脆い膜であることが認められた．他の可 塑剤を添加した膜は，低湿では非弾性变形であるが，高 湿では張力の変化に対する伸びの変化が大となり, 靶性 


\section{前田・元吉}

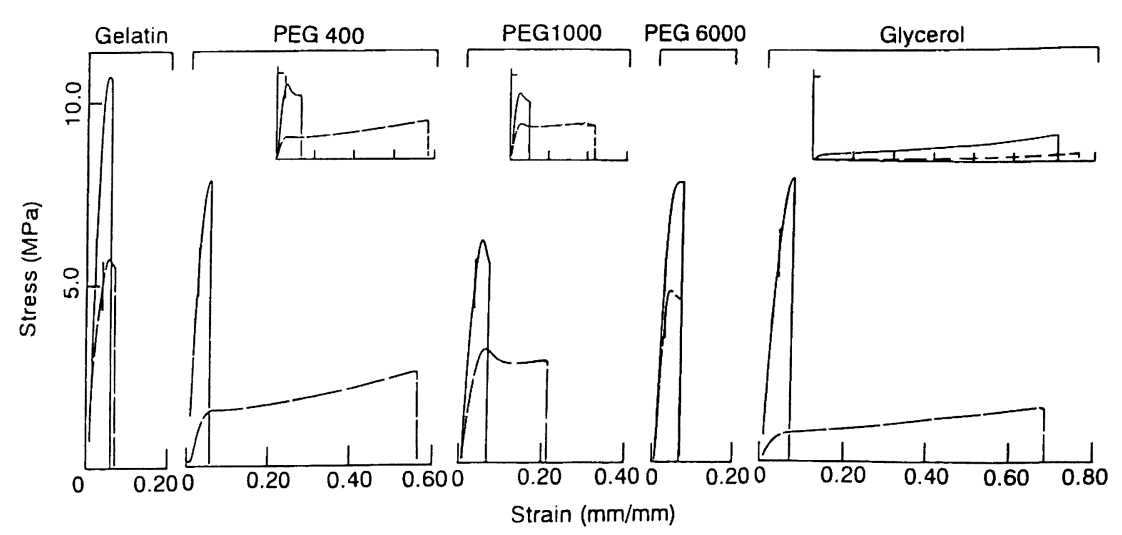

Fig. 7. Stress-strain curves of gelatin films containing PEG plasticizer ( $20 \%$ or $40 \%$ based on GE weight) crosslinked by $1 \mathrm{~h}$ reaction with formaldehyde vapor. Full line, $23^{\circ} \mathrm{C}, \mathrm{RH} 50 \%$; dotted line, $30^{\circ} \mathrm{C}, \mathrm{RH} 80 \%$.

変形機構により弾性変形する. 添加量を $40 \%$ に增やす 之, 低湿でも弾性変形し柔軟な膜となった。この場合, PEG 10 は降伏点が明確で, PEG4 ではやや不明確で, GL では消失する.このことから, 膜の網目構造が可塑 剤および吸湿により変化することがわかる.

\section{4 結 論}

PEG を添加した GE 乾燥膜を FA 蒸気で架橋し, GL 添加膜と効果を比較した.

GL は 80\% 添加してもゲル化を経て均一な膜が得ら れるが，PEG10 は60\% 以上，PEG60 は 20\% 以上添加 するとゲル化せず，正常な膜を調製できなかった．ま た, PEG4 は 40\% 以上添加すると膜から出た。 PEG4 と PEG 10 は GL と同様, 同じ架橋時間では GE 単独膜よりも溶解性が低下し, PEG60は, 単独膜との 差が小さかった。これらの膜は架橋時間により生分解性 を調整できると考えられるが, さらに, 微生物存在下で の分解性との相関を検討する必要がある.

GL とは反対に, PEG は GE 膜の耐熱性を向上させ, 高分子量で架橋時間が長いほど熱变性温度が高くなっ た。低分子量で添加量が多いほど低湿之高湿の吸湿度の 差が大となるが，GLょりは小さかった，引張強さは, PEGの添加により低下し, 添加量加增すと顕著になる. 低湿では分子量による差異は小さいが, 高湿では低分子 量ほど低下が大であったが, 両条件下とも GLょりは高 い値を示した。引裂強さは，GLよりも低湿と高湿の差 が大となった. また, PEG4 と PEG60 は架橋時間の影 響が明確であった，低湿ではPEG の分子量と添加量の 延伸率への影響は少ないが, 高湿ではPEG4 と PEG10 で単独膜より大となった。 PEG4 あるいはPEG10を 40\% 以上添加すると, 低湿でも弾性が付与され柔軟な 膜になった。
以上のことは, 可塑剤が GE のゲル化, 網目構造の形 成と弛緩，FA 蒸気の膜への浸透などに及ぼす効果だけ でなく, 乾燥膜中での GE との親和性, 吸湿性, 溶解性 などが相互に影響して起こるすのと考える. 膜の透明 性, 溶解性の調整, 物理特性, 化学特性, 吸湿による変 化などを総合評価すると, PEG10 が可塑剤として適し ていると思われる.

\section{文献}

1) 諸貫秀樹, 工業材料, 38(1), 26 (1990).

2) 角岡正弘, 合成樹脂, 38(2), 4 (1992).

3）野口 勉, 宮下真由美, 松手雅隆, Polym. Prepr., Jpn., 43, 1650 (1994).

4) Y. Doi, M. Kunioka, Y. Nakamurn, and K. Soga, Macromolecules, 81, 2722 (1988).

5) 国岡正雄, 高分子論文集， 50, 10755 (1993).

6) Y. Poirier, D. E. Dennis, K. Klomparens, and C. R. Someriville, Science, 256, 520 (1992).

7) Y. Tokiwa, T. Suzuki, and T. Ando, J. Appl. Polym. Sci. 24, 1701 (1978).

8) C. Bastioli, V. Bellotti, L. Del Giudice, G. Gilli, and J. Environ, Polym. Degr., 1(3), 181 (1993).

9) H. Otey, P. Westhoff, and M. Doane, Ind. Eng. Chem. Res., 26, 1659 (1987).

10) J. Hosokawa, M. Nishiyama, K. Yoshihara, and T. Kubo, Ind. Eng. Chem. Res., 29(5), 800 (1990).

11) 安井三雄, 岡前孝志, 山下岩男, Polym. Prepr., Jpn., 39, 2271 (1990).

12）隅田 卓, 兵庫県工業技術情報, [109], 8 (1993).

13) 前田拓也, 元吉治雄, 高分子論文集, 53, 155 (1996).

14）前田拓也, 元吉治雄, 高分子論文集, 53, 506 (1996).

15) F. Kawai and H. Yamanaka, Arch. Microbiol., 146, 125 (1986).

16) F. O'Flaherty, W. T. Roddy, and R. M. Lolly, Chemistry and Technology of Leather, 2, 50 (1958). 
Effects of the Poly(ethylene glycol) Addition on the Properties of Gelatin Films Crosslinked with Formaldehyde Vapor*

Takuya MAEDA*1 and Haruo Motoyoshi*1

*Studies on Development of Diodegradable Plastics Using Gelation III.

*1Industrial Technology Center of Wakayama Prefecture (60 Ogura, Wakayama, 649-62 Japan)

Dried gelatin (GE) films containing poly(ethylene glycol) (PEG) were crosslinked by the reaction with formaldehyde vapor (FA). Effects of the PEG content and its molecular weight on the properties of the films have been studied. The addition of PEG resulted in the more elastic and softer films. With an increase in the reaction time, the crosslink reaction proceeded from the surface into inside of the film, and consequently the water solubility of the film decreased. Depending on the molecular weight of PEG, the dissolution mode of the film into water varied due to the difference in osmotic function of PEG for FA. As the molecular weight of added PEG increased, the thermal stability of the film increased, and the change in the water vapor absorptivity with humidity change decreased. Tensile strength of the film was lowered by the addition of PEG, and the degree of deterioration was accelerated by an increase in PEG content. Under high humidity condition, the degree of elongation and tear strength were greatly influenced by the molecular weight, PEG content, and the time of crosslink reaction.

KEY WORDS Gelatin / Poly (ethylene glycol) / Formaldehyde Vapor / Biodegradability /

(Received September 9, 1996: Accepted December 2, 1996)

[Kobunshi Ronbunshu, 54(3), 138-143 (1997)] 